\title{
UPAYA PERAWAT DALAM PENCEGAHAN PRESSURE ULCER DI RSUD MARDI WALUYO KOTA BLITAR
}

\section{NURSE EFFORTS IN THE PREVENTION OF ULCER PRESSURE IN MARDI WALUYO HOSPITAL, BLITAR CITY}

\author{
Sunarti, Saputri Diah \\ Keperawatan Poltekkes Kemenkes Malang
}

\begin{abstract}
ABSTRAK
Pressure ulcer (dekubitus) biasanya dijumpai pada orang-orang yang di rawat di tempat tidur atau mengalami penurunan mobilitas, terutama bila disertai dengan status nutisi yang buruk. Tujuan dari penelitian ini adalah untuk mengetahui gambaran Upaya Perawat Dalam Pencegahan Pressure Ulcer di RSUD Mardi Waluyo Kota Blitar. Penelitian ini menggunakan desain penelitian deskriftif. Populasi penelitian ini adalah 54 perawat di ruang Melati, ruang Mawar, dan ruang Bougenvile RSUD Mardi Waluyo Kota Blitar dengan teknik total sampling. Pengumpulan data dilakukan dengan memberikan kuesioner. Waktu pengambilan data dilakukan pada tanggal 08-30 Juni 2016. Hasil penelitian menunjukkan upaya perawat $70,4 \%$ (38 perawat) cukup. Berdasarkan parameter, perawatan hygiene dan perawatan kulit topikal $72,2 \%$ (39 perawat) cukup, pencegahan mekanik dan alat pendukung 87,0\% (47 perawat) cukup, pendidikan kesehatan 96,3\% (52 perawat) baik. Rekomendasi dalam penelitian ini, diharapkan perawat terus mengikuti pelatihan dalam pencegahan dekubitus, dan menggunakan buku panduan seperti SOP dalam melakukan setiap tindakan asuhan keperawatan.
\end{abstract}

Kata kunci : Upaya, Perawat, Pressure Ulcer.

Pressure ulcers (decuitus) are usually found in people who are treated in bed or have decreased mobility, especially if accompanied by poor nutritional status. The purpose of this study was to determine the picture of Nurses' Efforts in Preventing Pressure Ulcers at Mardi Waluyo District Hospital in Blitar City. This research uses descriptive research design. The population of this study was 54 nurses in Melati room, Mawar room, and Bougenvile room Mardi Waluyo Regional Hospital in Blitar City using total sampling technique. Data collection was done by giving questionnaires. When the data was collected on June 8-30, 2016. The results showed that the efforts of nurses $70.4 \%$ (38 nurses) were sufficient. Based on parameters, $72.2 \%$ (39 nurses) are adequate, hygiene care and topical skin care, mechanical prevention and support tools $87.0 \%$ (47 nurses) are sufficient, health education 96.3\% (52 nurses) is good. Recommendations in this study, nurses are expected to continue training in the prevention of pressure sores, and use guidebooks such as SOPS in carrying out every action of nursing care.

Keyword: Efforts, Nurses, Pressure Ulcers.

Balimedikajurnal.com 
DOI: https://doi.org/10.36376/bmj.v6i2

\begin{tabular}{ll}
\hline Alamat Korespondensi & $\begin{array}{l}\text { : Jl. Besar Ijen No.77C, Oro-oro Dowo, Kec. Klojen, Kota Malang, } \\
\text { Jawa Timur. } \\
\text { Email }\end{array}$ \\
\hline
\end{tabular}

\section{PENDAHULUAN}

Ulkus dekubitus disebut juga pressure sores atau bed sores adalah lesi di kulit yang terjadi akibat rusaknya epidermis, dermis, dan kadang-kadang jaringan subkutis dan tulang di bawahnya (Corwin, 2009). Pressure ulcer muncul akibat empat faktor: tekanan, gesekan, friksi, dan lembab (Corwin, 2009).

Departemen Kesehatan Republik Indonesia (2001) menetapkan target sasaran mutu dimana pasien tidak menjadi dekubitus harus 0\% (Lumenta 2008, yang diadopsi dari indikator mutu pelayanan rumah sakit menurut World Health Organization (WHO) (Elyzabeth, 2010). Di Indonesia, pernah dilakukan survei di Rumah Sakit Sardjito Yogyakarta tahun 2001. Dilaporkan bahwa dari 40 pasien yang tirah baring, 40\% menderita luka dekubitus. Setyajati (2001) melakukan survei di Rumah Sakit Dr. Moewardi Surakarta, didapatkan 38,18\% pasien mengalami luka tekan.

Secara keseluruhan Indonesia, kejadian luka tekan di rumah sakit mencapai 33\% (Elyzabeth, 2010). Perbandingan kejadian luka tekan berdasarkan tatanan pelayanan kesehatan menunjukkan bahwa presentase luka tekan di nursing home berkisar 2,4\% - 23\%, sedangkan di rumah sakit berkisar antara 2,7\% - 29,5\% (Elyzabeth, 2010:2). Di RSUD Mardi Waluyo sendiri, ada beberapa ruangan yaitu ruang Melati yang merupakan ruang penyakit dalam seperti diabetes mellitus, ruang Bougenvile yang merupakan ruang penyakit saraf (stroke) dan ruang Mawar yang merupakan ruang penyakit paru dan dalam yang pasiennya sangat rentan mengalami luka tekan (pressure ulcer).

Dalam hal ini, perawat sebagai tim kesehatan yang melakukan pelayanan secara menyeluruh memiliki tanggung jawab dalam pelayanan kesehatan, salah satunya adalah dalam pencegahan terjadinya pressure ulcer.

Upaya pencegahan dekubitus perlu memperhatikan pengetahuan, sikap dan perilaku yang dimiliki pleh perawat (Setiyawan, 2010). Menurut National Pressure Ulcer Advisory Panel (NPUAP-EPUAP) 2009 menetapkan 6 (enam) dimensi pencegahan dan penatalaksanaan luka tekan yang terdiri dari: pengkajian risiko, pengkajian kulit, nutrisi, pengaturan posisi, penggunaan alat penyanggah, dan populasi khusus (Elizabeth, 2010).

Tiga area intervensi keperawatan utama untuk mencegah terjadi pressure ulcer adalah perawatan kulit, yang meliputi higienis dan perawatan kulit topikal; pencegahan mekanik dan pendukung untuk permukaan, yang meliputi pemberian posisi, penggunaan tempat tidur dan kasur terapeutik; dan pendidikan kesehatan (Potter \& Perry, 2006). Sedangkan untuk tahap pertama pencegahan pressure ulcer adalah mengkaji faktor-faktor risiko klien (Potter \& Perry, 2006).

Berdasarkan studi pendahuluan yang dilakukan oleh peneliti angka kejadian dekubitus tahun 2015 di ruang melati dari 35 pasien masih ditemukan 1 pasien yang mengalami pressure ulcer (dekubitus) akibat bedrest yang terlalu lama. Berdasarkan hasil wawancara kepada Kepala Ruang Melati, selama ini sebagian perawat di RSUD Mardi Waluyo Kota Blitar sudah melakukan upaya pencegahan 
BMJ. Vol 6 No 2, 2019: 184-191

DOI: https://doi.org/10.36376/bmj.v6i2

pressure ulcer (dekubitus) secara optimal dengan cara alih baring, mengganti alas tidur dengan matras udara ataupun matras air. Namun, angka kejadian luka tekan (dekubitus) masih bisa ditemukan.

Berdasarkan fenomena di atas, peneliti tertarik untuk meneliti tentang "Upaya Perawat Dalam Pencegahan Pressure Ulcer di RSUD Mardi Waluyo Kota Blitar".

\section{METODE PENELITIAN}

Dalam penelitian ini, desain penelitian yang digunakan adalah desain penelitian deskriptif. Rancangan penelitian deskriptif bertujuan untuk menerangkan atau menggambarkan masalah penelitian yang terjadi berdasarkan karakteristik tempat, waktu, umur, jenis kelamin, sosial, ekonomi, pekerjaan, status perkawinan dan hidup (pola hidup), dan lain-lain (Aziz, 2008).

Populasi dalam penelitian ini adalah perawat di 3 ruang RSUD Mardi Waluyo Kota Blitar yaitu Ruang Melati dengan jumlah perawat 20 orang, Ruang Bougenvile dengan jumlah perawat 18 orang, dan Ruang Mawar dengan jumlah perawat 16 orang sehingga total perawat di tiga ruang tersebut berjumlah 54 orang pada tahun 2016. Besar sampel dalam penelitian adalah perawat di 3 Ruang RSUD Mardi Waluyo Kota Blitar yaitu Ruang Melati, Ruang Bougenvile dan Ruang Mawar dengan total perawat 54 pada tahun 2016. Teknik pengambilan sampel pada penelitian ini menggunakan Total sampling.

\section{Analisis Data}

Analisa data yang digunakan oleh peneliti adalah dengan melakukan pengolahan data yang telah terkumpul hasilnya dijumlahkan dan dibandingkan dengan jumlah yang diharapkan setiap item soal dan diperoleh prosentase. Pengukuran upaya setiap jawaban Ya diberi skor 1 dan Tidak diberi skor 0 . Kemudian skor yang didapatkan dijumlahkan dan diprosentasekan menggunakan rumus (Sutomo, 2011:53):

$$
\mathrm{P}=\frac{f}{n} \times 100 \%
$$

Keterangan:

$$
\begin{aligned}
& P \text { : Prosentase } \\
& \mathrm{f} \text { : Jumlah jawaban yang diberikan } \\
& \mathrm{n} \text { : Jumlah skor. }
\end{aligned}
$$

Penentuan tingkat upaya responden penelitian tentang upaya perawat dalam pencegahan pressure ulcer dengan cara mengkonversikannya ke dalam kategori sebagai berikut:

Nilai $76-100 \%=$ Baik

Nilai $56-75 \%=$ Cukup

Nilai $\leq 55 \% \quad=$ Kurang (Sutomo, 2011:54). 


\section{HASIL DAN PEMBAHASAN}

\section{HASIL PENELITIAN Karakteristik responden}

Penelitian dilaksanakan di Rumah Sakit Mardi Waluyo, yang beralamatkan di Jl. Kalimantan no. 113 Kota Blitar . Tempat penelitian meliputi 3 Ruangan yaitu ruang Melati, ruang Mawar, dan Ruang Bougenvile. Ruang Melati merupakan ruang bagi pasien yang memiliki riwayat penyakit dalam khususnya penyakit Diabetes Mellitus dengan jumlah perawat di ruang Melati berjumlah 20 orang.

Data karakteristik responden terdiri dari umur, jenis kelamin, lama bekerja, pendidikan terakhir, mengikuti pelatihan PPI, menjadi anggota PPI, dan menggunakan alat-alat medis.

Hasil penelitian menunjukkan sebagian $46,3 \%$ (25 perawat) berumur $31-35$ tahun, sebagian besar $61,1 \%$ (33 perawat) berjenis kelamin perempua, hampir seluruhnya $92,6 \%$ (50 perawat) bekerja $1-15$ tahun, sebagian besar $63,0 \%$ (34 perawat) berpendidikan D3, hampir seluruhnya 90,7\% (49 perawat) mengikuti pelatihan PPI sebanyak 1x, hampir seluruhnya 96,3\% (52 perawat) tidak menjadi anggota PPI, sebagian besar 66,7\% (36 perawat) menggunakan SOP, dan seluruh perawat $100 \%$ (54 perawat) sudah menggunakan alat-alat medis sesuai prosedur.

\section{Upaya perawat mencegah pressure ulcer (dekubitus).}

Tabel 1 Upaya perawat mencegah pressure ulcer (dekubitus)

\begin{tabular}{llcc}
\hline No & $\begin{array}{c}\text { Kategori } \\
\text { Upaya }\end{array}$ & Frekuensi & Prosentase \\
\hline 1. & Baik & 14 & $25,9 \%$ \\
\hline 2. & Cukup & 38 & $70,4 \%$ \\
\hline 3. & Kurang & 2 & $3,7 \%$ \\
\hline \multicolumn{2}{c}{ Jumlah } & 54 & $100 \%$ \\
\hline
\end{tabular}

Dari tabel 1 diatas dapat diketahui bahwa sebagian besar yaitu 70,4\% (38 perawat) melakukan upaya cukup dalam mencegah pressure ulcer (dekubitus).

\section{Perawatan hygiene dan perawatan topikal}

Tabel 2 Upaya perawat mencegah pressure ulcer (dekubitus) dalam perawatan hygiene dan perawatan topikal

\begin{tabular}{|c|l|c|c|}
\hline No & $\begin{array}{c}\text { Kategori } \\
\text { Upaya }\end{array}$ & Frekuensi & Prosentase \\
\hline 1. & Baik & 6 & $11,1 \%$ \\
\hline 2. & Cukup & 39 & $72,2 \%$ \\
\hline 3. & Kurang & 9 & $16,7 \%$ \\
\hline \multicolumn{2}{|c|}{ Jumlah } & 54 & $100 \%$ \\
\hline
\end{tabular}

Dari tabel 2 dapat diketahui bahwa sebagian besar yaitu 72,2\% (39 perawat) melakukan upaya cukup dalam perawatan hygiene dan perawatan topikal. 
BMJ. Vol 6 No 2, 2019: 184-191

ISSN : 2615-7047

DOI: https://doi.org/10.36376/bmj.v6i2

Pencegahan mekanik dan alat pendukung

Tabel 3 Upaya dalam mencegah pressure ulcer (dekubitus) dengan pencegahan mekanik dan alat pendukung

\begin{tabular}{|c|l|c|c|}
\hline No & $\begin{array}{c}\text { Kategori } \\
\text { Upaya }\end{array}$ & Frekuensi & Prosentase \\
\hline 1. & Baik & 4 & $7,4 \%$ \\
\hline 2. & Cukup & 47 & $87,0 \%$ \\
\hline 3. & Kurang & 3 & $5,6 \%$ \\
\hline \multicolumn{2}{|r|}{ Jumlah } & 54 & $100 \%$ \\
\hline
\end{tabular}

Dari tabel 3 dapat diketahui bahwa upaya cukup dalam mencegah pressure ulcer (dekubitus) dengan pencegahan mekanik dan alat pendukung yaitu 87,0\% (47 perawat).

\section{Pendidikan kesehatan}

Tabel 4 Upaya dalam mencegah pressure ulcer (dekubitus) dengan pendidikan kesehatan

\begin{tabular}{|c|l|c|c|}
\hline No & $\begin{array}{c}\text { Kategori } \\
\text { Upaya }\end{array}$ & Frekuensi & Prosentase \\
\hline 1. & Baik & 52 & $96,3 \%$ \\
\hline 2. & Cukup & 0 & $0 \%$ \\
\hline 3. & Kurang & 2 & $3,7 \%$ \\
\hline \multicolumn{2}{|c|}{ Jumlah } & 54 & $100 \%$ \\
\hline
\end{tabular}

Dari tabel 4 dapat diketahui bahwa upaya baik dalam mencegah pressure ulcer (dekubitus) dengan pendidikan kesehatan yaitu 96,3\% (52 perawat).

\section{PEMBAHASAN}

Berdasarkan hasil penelitian upaya perawat dalam pencegahan pressure ulcer (dekubitus) di Rumah Sakit Mardi Waluyo Kota Blitar kepada 54 perawat dengan total 97 pasien yang terbagi dalam tiga ruang yaitu 35 pasien di ruang melati, di 34 pasien di ruang Mawar, 28 pasien di ruang Bougenvile didapatkan data upaya perawat dalam pencegahan pressure ulcer (dekubitus) yaitu 70,4\% (38 perawat) melakukan upaya cukup dalam mencegah pressure ulcer (dekubitus), 25,9\% (14 perawat) melakukan upaya baik dalam mencegah pressure ulcer (dekubitus), dan 3,7 (2 perawat) melakukan upaya kurang dalam mencegah pressure ulcer (dekubitus). Menurut Kamus Besar Bahasa Indonesia, upaya adalah usaha, ikhtiar untuk mencapai suatu maksud dan memecahkan persoalan. Sedangkan penceghaan adalah proses, cara, tindakan mencegah atau tindakan menahan agar sesuatu tidak terjadi (Depdiknas, 2008).

Menurut peneliti upaya pencegahan dekubitus perlu memperhatikan pengetahuan, sikap, dan perilaku yang dimiliki oleh perawat. Perawat perlu memiliki sikap yang positif yang akan mempengaruhi perilakunya dalam mencegah dekubitus yang dimanifestasikan dalam bentuk tanggapan atau respon perasaan positif perawat terhadap tindakan-tindakan pencegahan dekubitus. 
DOI: https://doi.org/10.36376/bmj.v6i2

\section{Perawatan higiene dan perawatan kulit topikal}

Berdasarkan hasil penelitian menunjukkan bahwa 72,2\% (39 perawat) cukup dalam melakukan perawatan hygiene dan perawatan kulit topikal, 11,1\% (6 perawat) dengan upaya baik, dan 16,7\% (9 perawat) dengan upaya kurang. Menurut data yang diperoleh pada parameter pertama, didapatkan pernyataan mengkaji riwayat penyakit saat awal masuk rumah sakit $100 \%$ sudah dilakukan secara optimal oleh perawat. Menurut Potter \& Perry (2006) data dasar pengkajian yang terus-menerus memberi informasi penting tentang integritas kulit klien dan peningkatan risiko terjadi dekubitus.Menurut peneliti, pengkajian awal pada pasien sangat membantu perawat dalam mengidentifikasi apakah pasien tersebut berisiko mengalami luka tekan, sehingga bila klien teridentifikasi berisiko maka intervensi yang tepat diberikan untuk mempertahankan integritas kulit.Menurut data yang diperoleh pada parameter pertama, masih ada satu pernyataan yang belum optimal dilakukan oleh perawat, seperti pada penyataan melakukan massase pada kulit pasien 2x sehari 20\% sudah optimal, $80 \%$ belum optimal. Menurut Vander Cammen (1991) yang dikutip oleh Pranarka (1999) menyatakan bahwa pada dekubitus Stadium I, kulit yang tertekan dan kemerahan harus dibersihkan menggunakan air hangat dan sabun, lalu diberi lotion dan dipijat 2-3 x/ hari untuk memperlancar sirkulasi sehingga iskemia jaringan dapat dihindari (Maryam 2010:). Menurut Kowalak (2011) masase kulit pasien yang dilakukan dengan lembut di sekitar daerah lesi, bukan pada tempat lesi yang akan mempercepat kesembuhan.Menurut peneliti, melakukan massase 2-3x/hari di sekitar daerah lesi, bukan pada tempat lesi merupakan tindakan efektif dalam mencegah terjadinya luka tekan (dekubitus), karena tindakan tersebut dapat meningkatkan sirkulasi pada daerah yang di massase, meningkatkan relaksasi, menjaga keadaan kondisi kulit, memperlancar metabolisme sel pada kulit, dan dapat mempercepat proses penyembuhan pada daerah lesi.

\section{Pencegahan mekanik dan alat pendukung permukaan}

Berdasarkan hasil penelitian menunjukkan bahwa 87,0\% (47 perawat) cukup dalam melakukan pencegahan mekanik dan pemberian alat pendukung permukaan, $7,4 \%$ (4 perawat) baik dalam melakukan pencegahan mekanik dan pemberian alat pendukung permukaan, dan 5,6\% (3 perawat) kurang dalam melakukan pencegahan mekanik dan pemberian alat pendukung permukaan.

Menurut data yang diperoleh pada parameter kedua, didapatkan pernyataan memasang matras udara atau matras air $91 \%$ sudah dilakukan secara optimal meskipun $9 \%$ belum dilakukan secara optimal oleh perawat. Menurut Potter \& Perry (2006) berbagai jenis alas pendukung, termasuk kasur dan tempat tidur khusus, telah dibuat untuk mengurangi bahaya mobilisasi pada sistem kulit dan musculoskeletal.

Menurut peneliti, penggunaan matras udara atau air sangat penting. Bila kasur dan tempat tidur digunakan dengan tepat, maka alat-alat tersebut akan membantu mengurangi dekubitus pada klien yang berisiko.

Menurut data yang diperoleh pada parameter kedua, masih ada satu pernyataan yang belum optimal dilakukan oleh perawat, seperti pernyataan mempertahankan kepala tempat tidur pada posisi $30^{\circ}$ untuk mencegah pasien merosot $24 \%$ sudah optimal, 76\% belum optimal. Menurut Potter \& Perry (2006) dengan menjaga bagian kepala tempat tidur setinggi $30^{\circ}$ atau kurang akan menurunkan peluang 
DOI: https://doi.org/10.36376/bmj.v6i2

terjadi dekubitus akibat gaya gesek (AHCPR, 1992). Menurut Maryam (2010) pertahankan kepala tempat tidur pada posisi $30^{\circ}$ atau di bawah $30^{\circ}$ untuk mencegah pasien merosot yang dapat mengakibatkan terjadinya perobekan jaringan.Menurut peneliti, posisi kepala tempat tidur setinggi $30^{\circ}$ sangat membantu dalam menurunkan peluang terjadinya dekubitus. Posisi tersebut mencegah pasien merosot dari tempat tidur sehingga menghindari pergesekan antara kulit pasien dengan tempat tidur.

\section{Pendidikan kesehatan}

Berdasarkan hasil penelitian menunjukkan bahwa 96,3\% (52 perawat) dengan upaya baik dalam memberikan pendidikan kesehatan, dan 3,7\% (2 perawat) dengan upaya cukup. Menurut data yang diperoleh pada parameter ketiga, didapatkan pernyataan memberikan pendidikan kesehatan tentang dekubitus $100 \%$ sudah dilakukan secara optimal oleh perawat. Menurut Potter \& Potter (2006) ada berbagai macam alat untuk melakukan pendidikan kesehatan, antara lain kaset video dan keterangan tertulis, yang dapat digunakan perawat ketika memberikan pendidikan kesehatan pada klien dan pemberi perawatan/keluarga yang bertujuan mencegah dan mengobati pressure ulcer. Keterangan tertulis yang terdiri dari berbagai jenis topik, antara lain mengganti balutan, pedoman melakukan tindakan pada luka, dan gambar memposisikan klien. Menurut Notoatmodjo (1993), pendidikan kesehatan dapat dilakukan dengan menggunakan berbagai metode dan pendekatan. Salah satunya dengan melakukan bed side teaching dimana hanya membutuhkan waktu sekitar 10-15 menit sambil perawat melakukan tugas keperawatannya seperti saat membantu mobilisasi, memberi makan atau saat memandikan klien. Dengan menggunakan berbagai media yang menarik dan jelas tentunta akan membantu klien dan keluarganya dan meningkatkan pengetahuan guna melakukan perawatan diri (Maryam, 2010). Menurut peneliti, pendidikan kesehatan tentang pencegahan dekubitus perlu diberikan saat pasien masuk rumah sakit sampai pasien pulang dari rumah sakit. Pendidikan kesehatan tidak hanya diberikan kepada pasien, namun keluarga pasien juga perlu mendapatkan pendidikan kesehatan karena pasien akan lebih sering berkomunikasi dengan keluarga dibandingkan dengan perawat.

\section{SIMPULAN DAN SARAN}

\section{Simpulan}

Berdasarkan hasil penelitian upaya perawat dalam pencegahan pressure ulcer di RSUD Mardi Waluyo Kota Blitar pada bulan Juni 2016, menunjukkan bahwa:

Upaya perawat dalam pencegahan pressure ulcer (dekubitus) secara umum yaitu $70,4 \%$ (38 perawat) melakukan upaya cukup dalam mencegah pressure ulcer (dekubitus). Upaya perawat dalam mengkaji riwayat penyakit saat awal masuk rumah sakit $100 \%$ sudah dilakukan secara optimal, memasang matras udara atau matras air 91\% sudah dilakukan secara optimal meskipun 9\% belum dilakukan secara optimal dan memberikan pendidikan kesehatan tentang dekubitus $100 \%$ sudah dilakukan secara optimal oleh perawat. Sedangkan melakukan massase pada kulit pasien $2 x$ sehari $20 \%$ sudah dilakukan secara optimal, $80 \%$ belum dilakukan secara optimal, dan mempertahankan kepala tempat tidur pada posisi $30^{\circ}$ untuk 
BMJ. Vol 6 No 2, 2019: 184-191

ISSN : $2615-7047$

DOI: https://doi.org/10.36376/bmj.v6i2

mencegah pasien merosot $24 \%$ sudah dilakukan secara optimal, $76 \%$ belum dilakukan secara optimal oleh perawat.

\section{Saran}

Bagi Institusi Pendidikan

Hasil penelitian ini diharapkan dapat digunakan sebagai referensi tambahan untuk proses pembelajaran mengenai upaya perawat dalam pencegahan pressure ulcer (dekubitus).Bagi UPTD Kesehatan Kecamatan Sukorejo Kota Blitar Bagi Tempat Penelitian (RSUD Mardi Waluyo Kota Blitar)

Diharapkan hasil penelitian dapat digunakan sebagai sumber informasi dan RSUD Mardi Waluyo Kota Blitar dapat meningkatkan upaya perawat dalam pencegahan pressure ulcer (dekubitus) dengan mengikuti pelatihan pasien safety, selanjutnya memberikan pendidikan kesehatan kepada pasien dan keluarga tentang cara pencegahan pressure ulcer (dekubitus) selama di rumah sakit.

a) Bagi Peneliti Selanjutnya

Diharapkan hasil penelitian ini dapat dijadikan data dasar untuk melakukan penelitian lebih lanjut yang berkaitan dengan upaya perawat dalam pencegahan pressure ulcer (dekubitus).

\section{DAFTAR PUSTAKA}

Aziz Alim ul Hidayat, 2008. Riset Keperawatan dan Tehnik Penulisan Ilmiah. Jakarta: Penerbit Salemba Medika.

Corwin 2009 Buku Saku Patofisiologi Kedokteran Edisi ke 3 Jakarta,EGC

Departemen Pendidikan Nasional. 2008. Kamus Besar Bahasa Indonesia Pusat Bahasa. Jakarta: PT Gramedia Pustaka Utama.

Elizabeth J.C, 2009. Buku Saku Patofisiologi, Ed. 3. Jakarta: Penerbit Buku Kedokteran EGC.

Elysabeth D.T,T. 2010. Pengaruh Posisi Miring 30 derajat Terhadap Kejadian Luka Tekan Grade I (Non Blanchable Erythema) Pada Pasien Stroke Di Siloam Hospital (diakses pada tanggal 21 Desember 2015).

Maryam R.S. 2010. Dekubitus, bagaimana perawat mencegahnya?. (Diakses pada tanggal 18 Januari 2016).

Notoatmodjo, 2010. Metodologi Penelitian Kesehatan. Jakarta: RINEKA CIPTA.

Potter \& Perry, 2005. Fundamental Keperawatan : konsep, proses, dan praktik Edisi 4. Jakarta: Penerbit Buku Kedokteran EGC.

Potter, Patricia A. 2005. Buku Ajar Fundamental Keperawatan: Konsep, Proses, dan Praktik, VOL. 1, E/4. Jakarta: EGC.

Setiadi, 2013. Konsep dan Praktik Penulisan Riset Keperawatan. Yogyakarta: Graha Ilmu.

Setiyawan. 2010. Hubungan Tingkat Pengetahuan dan Sikap Dengan Perilaku Perawat Dalam Upaya Pencegahan Dekubitus Di Rumah Sakit Cakra Husada Klaten. (Diakses pada tanggal 11 Januari 2015).

Sutomo, A.H. 2011. Teknik Menyusun KTI-Skripsi-Tesis-Tulisan Ilmiah Dalam Jurnal Bidang Kebidanan, Keperawatan Dan Kesehatan. Yogyakarta: Fitramaya.

Balimedikajurnal.com 